\title{
Mechanism of Histamine-induced
}

\section{Excitation of the Cat Pylorus}

\author{
P. Biancani, L. K. CiCalzi, and R. W. McCallum, Veterans Administration \\ Medical Center and Yale University, West Haven, Connecticut 06516
}

\begin{abstract}
A B S T RAC T Intravenous histamine causes high amplitude repetitive phasic contractions of the in vivo cat pylorus but has little effect on the antrum and duodenum. The genesis of this phasic response was studied using a pinned perfused catheter with openings at the pylorus, antrum, and duodenum. 2-Pyridylethylamine, an $\mathrm{H}_{1}$ agonist, produced phasic contractions similar to histamine whereas dimaprit, an $\mathbf{H}_{2}$ agonist, did not. Conversely, histamine-induced excitation is competitively antagonized by the $\mathrm{H}_{1}$ inhibitor diphenhydramine but not by the $\mathrm{H}_{2}$ inhibitor cimetidine. Thus histamine excitation is mediated through $\mathrm{H}_{1}$ receptor stimulation.
\end{abstract}

Tetrodotoxin caused inhibition of the histamine response indicating that pyloric excitation is partly mediated through a neural pathway. To identify the nature of this pathway adrenergic and cholinergic blockers were used. Atropine, hexamethonium, and propranolol had no effect on the histamine response. Phentolamine and reserpine increased the magnitude of the histamine response. Conversely, phenylephrine blocked the histamine response.

We conclude: histamine induces high phasic contractions in the pylorus; this effect is mediated through neural (nonadrenergic noncholinergic) and myogenic $\mathrm{H}_{1}$ receptors; alpha adrenergic stimulation inhibits the histamine response and alpha adrenergic blockade and catecholamine depletion increase it.

\section{INTRODUCTION}

Histamine is present in most tissues of the body, in man and animal alike, but is present in higher concentration in the stomach than in the remainder of the intestinal tract (1). Histamine has been reported to have important effects on gastric microcirculation (2), on motility of the stomach (3-5) and lower esophageal sphincter (6-8), and on gastric secretion (9). Of three endogenous substances known to stimulate gastric

Received for publication 21 July 1980 and in revised form 3 April 1981. secretion, acetylcholine, gastrin, and histamine, the role of histamine is perhaps the more uncertain. Gastric secretion, however, is inhibited by $\mathrm{H}_{2}$ antagonists even in the presence of gastrin and other oxyntic cell stimulants (9), suggesting a central role of histamine in acid secretion, either as a final common mediator or as a facilitating agent for the action of other mediators.

Despite these multiple and important effects of histamine on the stomach, little is known about its effect on either gastric emptying or on pyloric motility.

It is the purpose of this investigation to define the effect of histamine on the cat pylorus and to examine neural and myogenic pathways mediating this response.

\section{METHODS}

These studies were performed in 50 adult cats of either sex weighing $3-5 \mathrm{~kg}$ after fasting for $16 \mathrm{~h}$. The animals were anesthetized with a combination of intramuscular ketamine hydrochloride $(10 \mathrm{mg} / \mathrm{kg})$ and intraperitoneal urethane $(0.5 \mathrm{~g} / \mathrm{kg})$. Maintenance doses of $2.5-5 \mathrm{mg} / \mathrm{kg}$ ketamine were administered throughout the experiment as needed. Adequate ventilation was assured by maintaining all animals on the respirator via a tracheostomy tube connected to a Harvard Apparatus respiration pump (Harvard Apparatus Co., Inc., S. Natick, Mass.). The animals were studied in the supine position, and normal saline was slowly infused through an intravenous cannula inserted in the right femoral vein. The right femoral artery was also cannulated and arterial blood pressure was recorded using a Statham pressure transducer (Statham Instruments, Inc., Oxnard, Calif.). Body temperature was maintained at $37^{\circ} \mathrm{C}$ by a heat lamp connected to an intrarectal Thermistor probe.

Lower esophageal sphincter (LES) ${ }^{1}$ and pyloric and duodenal pressures were measured simultaneously with two separate manometric catheters (Fig. 1A). The LES catheter consisted of a Dent sleeve (10) with two additional openings, one proximal, one distal to the sleeve. The sleeve was positioned at the lower esophageal sphincter high pressure zone with the proximal opening recording pressures in the esophagus and the distal opening recording pressures in the fundus. The pyloric catheter consisted of a hollow polyvinyl tube with an outside diameter (o.d.) of $5 \mathrm{~mm}$ having eight

\footnotetext{
${ }^{1}$ Abbreviations used in this paper: LES, lower esophageal sphincter; TTX, tetrodotoxin.
} 
small tubes with an o.d. of $1.3 \mathrm{~mm}$ glued with tetrahydrafuran, four on the anterior and four on the posterior aspects of the hollow tube. The final circumference of the entire assembly was $19 \mathrm{~mm}$, which is equivalent to an average o.d. of $6.05 \mathrm{~mm}$. Each small tube had a side opening. Six side openings, 2-7, were placed in a 3-mm space, three openings on the anterior and three openings on the posterior aspects of the tube. The first opening was $1 \mathrm{~cm}$ proximal to these six openings and the eighth was $1 \mathrm{~cm}$ distal. The catheters were connected to Statham pressure transducers and continuously perfused through a low compliance system (Arndorfer Medical Specialties, Greendale, Wis. 53129). Pressures were recorded on a Grass polygraph (Grass Instrument Co., Quincy, Mass.). Upon sudden occlusion of the distal tip the pressure rate of rise of this system was $400 \mathrm{~mm} \mathrm{Hg} / \mathrm{s}$. The pyloric probe was introduced into the antrum through a small duodenal incision $3 \mathrm{~cm}$ distal to the pylorus. The high pressure zone was identified by gradual pull-through with the six middle side openings. Then the catheter assembly was anchored using two metallic pins that were inserted through the wall of the gastroduodenal junction and hollow tube. One pin was introduced 1-2 mm distal to the anatomical pylorus; the other pin was introduced 5-6 mm distal to the pylorus. The location of the six middle openings was checked by tapping on the outside of the anatomical pylorus with the narrow side of a scalpel handle. When a side opening was present at the location pressed by the scalpel handle, each tap produced pressure spikes recorded from the catheter. With the openings thus placed at the anatomical pylorus, a high pressure was recorded in three or four of the six openings, indicating a pyloric length of $2-2.5 \mathrm{~mm}$. Thus the two openings that had the highest resting pressure were selected for the remainder of the study. The opening that exhibited the highest resting pressure in basal conditions produced the highest contractions in response to histamine. Throughout the study, the histamine response was taken as the average of three highest contractions at the one opening selected while the alternate opening served to confirm the first one. In some animals, all six pyloric openings were monitored throughout a whole dose-response study to several doses of histamine. At all doses, the highest contractions were recorded at the same side opening. This was taken as a confirmation of the fact that no longitudinal movement of the pylorus over the catheter occurred during the experiment.

After tracheostomy, both cervical vagus nerves were identified and carefully exposed. Each was tied off with a silk ligature and the nerve severed. The peripheral end of each nerve was stimulated with a Grass stimulator (Grass Instrument Co.) through wire electrodes placed around the end of the nerve. In a previous investigation (11), frequencyresponse studies were performed with electrical stimuli 5,10 , 20,40 , and $50 \mathrm{~Hz}$ at $40 \mathrm{~V}$ with 5 -s trains of square wave pulses, $0.5 \mathrm{~ms}$ in duration. Maximum relaxation was obtained at frequencies of $40-50 \mathrm{~Hz}$. Therefore in this study, the following stimulation parameters were used: frequency $50 \mathrm{~Hz}$ duration of pulses $0.5 \mathrm{~ms}$, amplitude $50 \mathrm{~V}$, train duration $5 \mathrm{~s}$. Relaxation during vagal stimulation occurred only at the catheters that exhibited high pressure located at the anatomical pylorus (11). The following pharmacological agents were used: histamine phosphate and atropine sulfate (Eli Lilly \& Company, Indianapolis, Ind.), diphenhydramine hydrochloride and epinephrine chloride (Parke-Davis, Div. of Warner-Lambert Company, Morris Plains, N. J.), cimetidine, 2-2 pyridylethylamine and dymaprit-di-hydrochloride (Smith Kline \& French Laboratories, Philadelphia, Pa.), tetrodotoxin (Calbiochem-Behring Corp., San Diego, Calif.), hexamethonium hydrochloride (City Chemical Corp., New York), propranolol hydrochloride (Ayerst Laboratories, New York), phentolamine mesylate and reserpine (Ciba-Geigy Corp.,
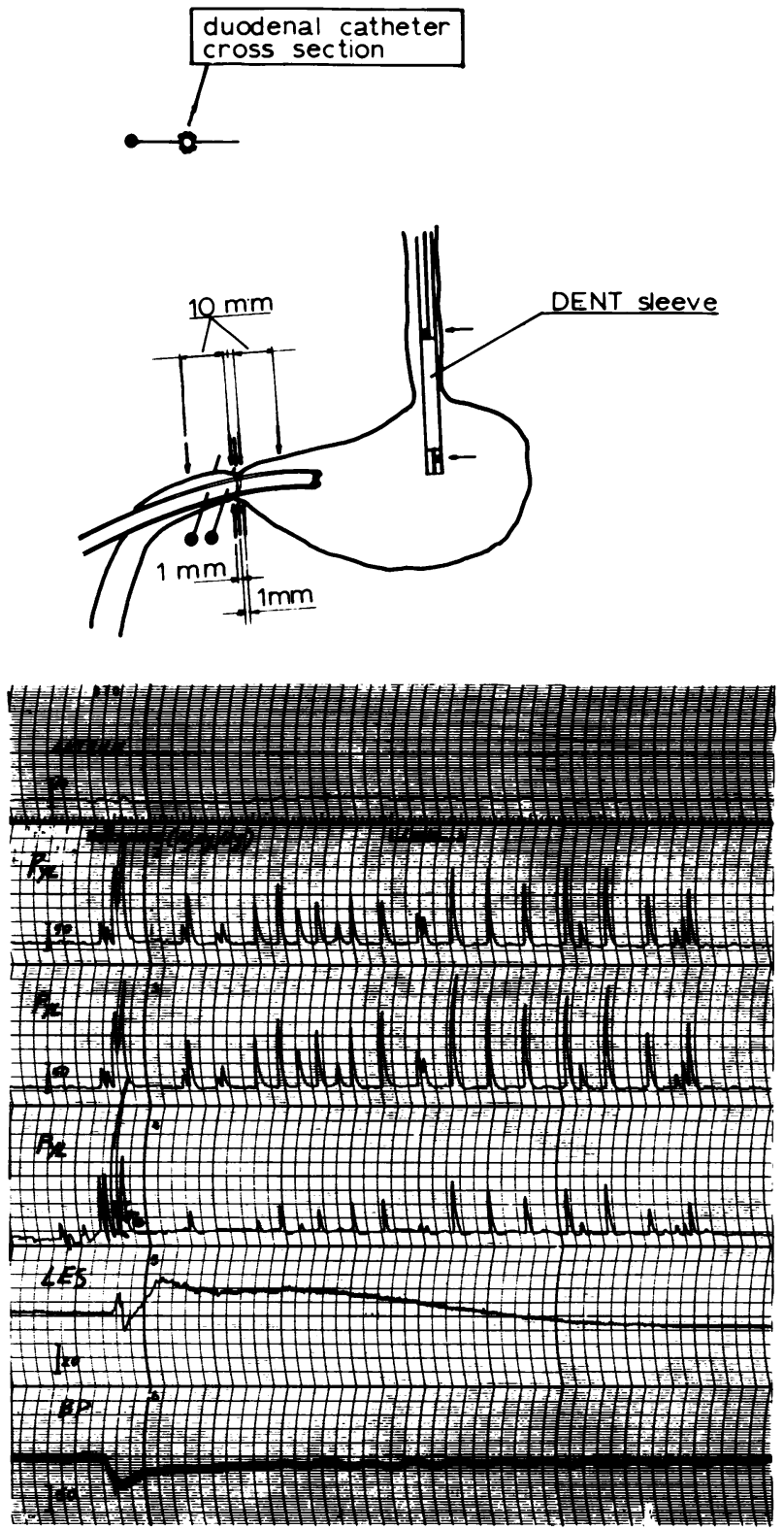

FIGURE 1 (A) Experimental set up. Arrows indicate openings in duodenal catheter. Lower esophageal sphincter pressure was measured with a "Dent sleeve." (B) Antral, pyloric (Pyl), lower esophageal sphincter (LES), and blood pressure (BP) response to intravenous bolus doses of histamine.

Summit, N. J.), and phenylephrine hydrochloride (Winthrop Laboratories, New York). Each pharmacologic antagonist was administered intravenously over a 30 -s period in doses sufficient to block the dose of its respective agonist that produced a maximal effect on the pylorus as previously determined (11).

A total dose of $20-30 \mu \mathrm{g} / \mathrm{kg}$ of tetrodotoxin was administered in successive $2.5-\mu \mathrm{g} / \mathrm{kg}$ i.v. increments spaced $5 \mathrm{~min}$ apart. After an initial fall, blood pressure stabilized and partially recovered after 30-45 $\mathrm{min}$. This dose is in excess of the dose required to inhibit pyloric relaxation $(10-12 \mu \mathrm{g} / \mathrm{kg})$ in 


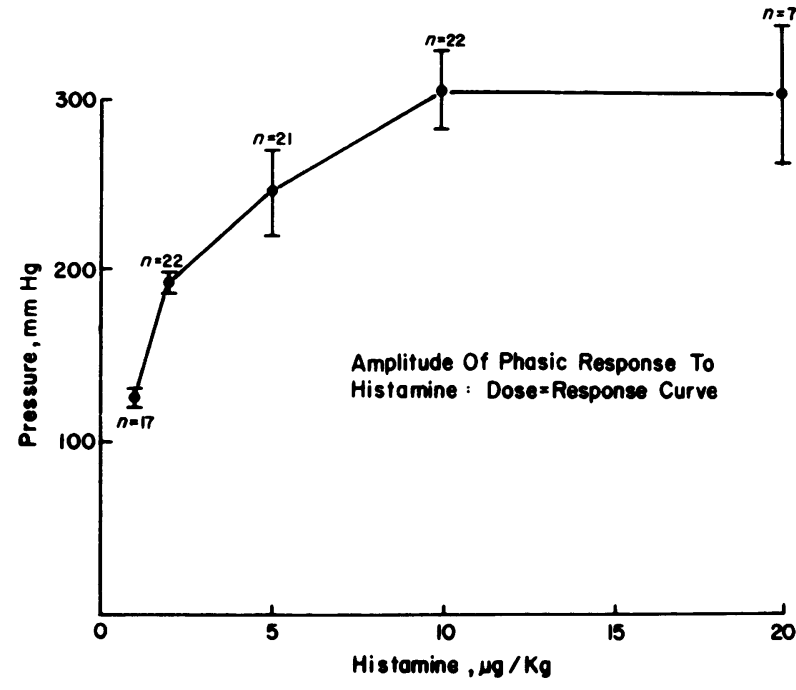

Figure 2 Dose-response curves to intravenous bolus injection of histamine. All values are mean \pm SEM.

response to efferent vagal stimulation. Completeness of denervation was tested by stimulating the femoral nerve. When femoral nerve stimulation failed to produce leg twitches, completeness of denervation was assumed.

Each animal was used to study the effect of a single agent. After preparing the animal, a single dose-response curve to histamine was obtained. Successive histamine doses were administered at 1-h intervals to avoid tachyphylaxis. A second dose-response curve was obtained after administering the appropriate antagonist. Each study lasted 8-9 h. The animals remained in good condition throughout the study. No decline in the amplitude of the responses was observed toward the end of the experiment. To this effect, however, it was important to separate successive doses by an appropriate time interval.

The doses referred to in the text apply to the salts. Data

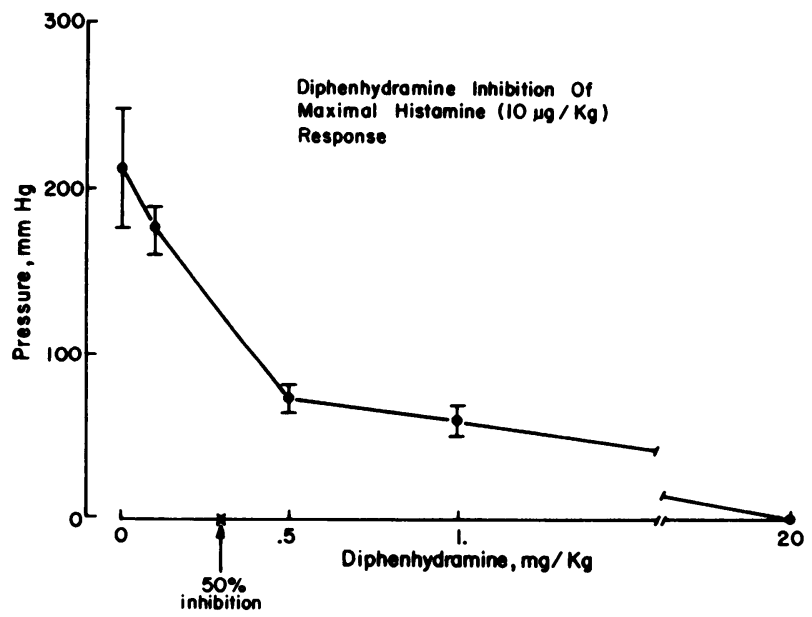

Figure 3 Dose-dependent diphenhydramine inhibition of pyloric response to histamine. Half-maximal inhibition occurs with $0.32 \mathrm{mg} / \mathrm{kg}$ diphenhydramine. All values are mean $\pm \operatorname{SEM}(n=3)$. were analyzed with the $t$ test for paired and unpaired variables, and nonparametric tests.

\section{RESULTS}

Histamine caused repetitive strong phasic contractions of the pyloric region with a frequency of 3-4 min as shown in Fig. 1B. This response is markedly different from the lower esophageal sphincter in which, after a single contraction, a relaxation occurred followed by a second prolonged contraction. The average of the three highest contractions from the pyloric catheter selected at the beginning of the experiment was taken as response to any given dose of histamine. These contractions were found to be strongest within the 2-mm region at the gastroduodenal junction and did not occur in the antrum or the duodenum at comparable magnitudes. (Contractions of lesser magnitude were occasionally observed propagated into the duodenum.) Pyloric contraction was dose related. A bolus dose of $0.5 \mu \mathrm{g} / \mathrm{kg}$ had no effect, whereas $1 \mu \mathrm{g} / \mathrm{kg}$ caused contractions in half the animals tested. Maximal pressures occurred with $10 \mu \mathrm{g} / \mathrm{kg}$ of histamine (Fig. 2). Doses in excess of $10 \mu \mathrm{g} / \mathrm{kg}$ did not significantly increase the magnitude of pyloric contractions and often had undesirable side effects (vomiting, cardiac arrest). $10 \mu \mathrm{g} / \mathrm{kg}$ of histamine was taken as a maximal dose in all subsequent studies.

A similar response was obtained with continuous perfusion of histamine in doses varying between 5 and $160 \mu \mathrm{g} / \mathrm{kg}$ per $\mathrm{h}$. In three animals these doses caused

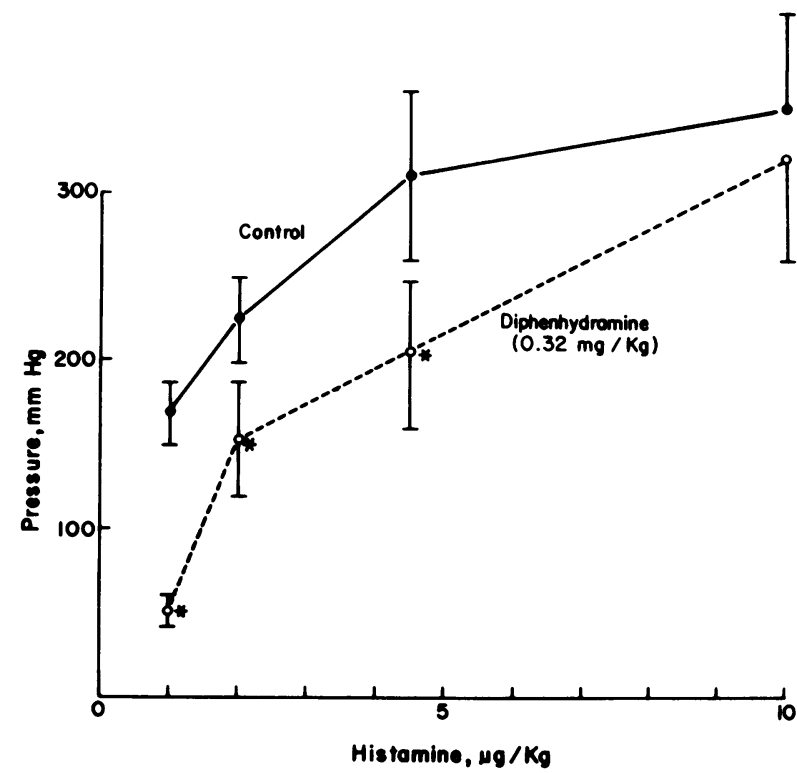

Figure 4 Effect of $D_{50}$ diphenhydramine on histamine dose-response curves. Stars denote statistically significant differences from control values. All values are mean \pm SEM $(n=4)$. 
repetitive contractions of amplitude varying between $90 \pm 8 \mathrm{~mm} \mathrm{Hg}($ mean $\pm \mathrm{SEM})$ at $5 \mu \mathrm{g} / \mathrm{kg}$ per h and $220 \pm 50 \mathrm{~mm} \mathrm{Hg}$ at $160 \mu \mathrm{g} / \mathrm{kg}$ per h. In the same animal species (12) histamine has been shown to maximally stimulate gastric acid secretion in doses varying between 160 and $320 \mu \mathrm{g} / \mathrm{kg}$ per h. Thus, a substantial pyloric stimulation occurs with doses of histamine lower than those required to produce maximal acid secretory response.

In three animals, after measuring the response to $10 \mu \mathrm{g} / \mathrm{kg}$ of histamine, the animals were allowed to rest for $1 \mathrm{~h}$ and then a single dose of diphenhydramine was given. $15 \mathrm{~min}$ later, $10 \mu \mathrm{g} / \mathrm{kg}$ of histamine was injected intravenously. $1 \mathrm{~h}$ was allowed between successive doses of histamine. The largest dose of diphenhydramine, $20 \mathrm{mg} / \mathrm{kg}$, was tested last. This dose completely inhibited the histamine's response; $50 \%$ inhibition occurred at $\sim 0.3 \mathrm{mg} / \mathrm{kg}$ as extrapolated from the dose-response curve (Fig. 3). The effect of the $E D_{50}$ dose of diphenhydramine on the histamine response is shown in Fig. 4. After obtaining a full dose-response curve to histamine, the animals were given $0.32 \mathrm{mg} / \mathrm{kg}$ of diphenhydramine 15 min before each new dose of histamine. One h was allowed between successive doses. $E_{50}$ diphenhydramine produced a significant reduction in response at low histamine doses, that is, at 1,2 , and $5 \mu \mathrm{g} / \mathrm{kg}$. The response to $10 \mu \mathrm{g} / \mathrm{kg}$ of histamine was unaltered by $E D_{50}$ diphenhydramine. These results are compatible with competitive inhibition response by diphenhydramine. The effect of an $\mathrm{H}_{2}$ antagonist, cimetidine, is shown in Fig. 5 . Cimetidine did not inhibit the histamine response; in fact $2 \mu \mathrm{g} / \mathrm{kg}$ increased it and did not affect the response significantly at other doses.

The response of the pylorus to specific $\mathrm{H}_{1}$ and $\mathrm{H}_{2}$ agonists is shown in Fig. 6. 2-Pyridyletyl-amine, a

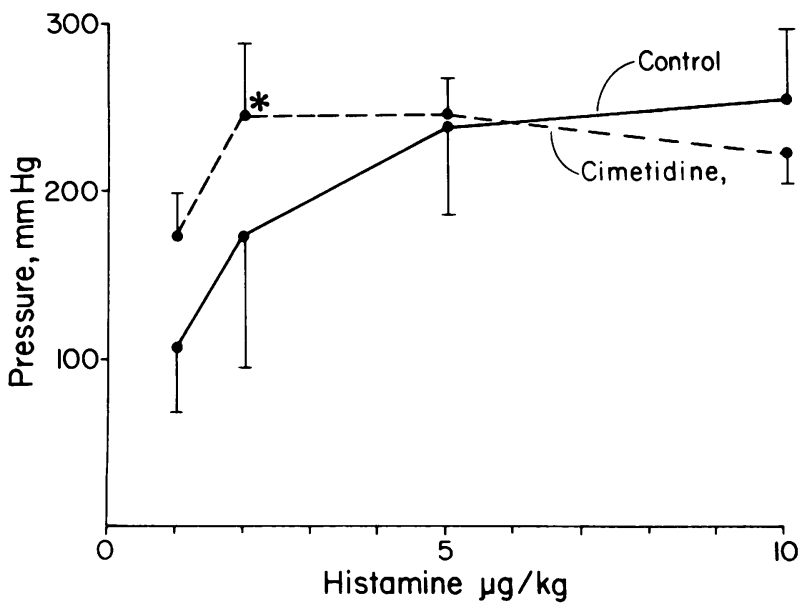

FIGURE 5 Effect of cimetidine $(5 \mathrm{mg} / \mathrm{kg}, n=5)$ on histamine dose-response curves. Stars denote statistically significant differences from control values $(n=5)$.

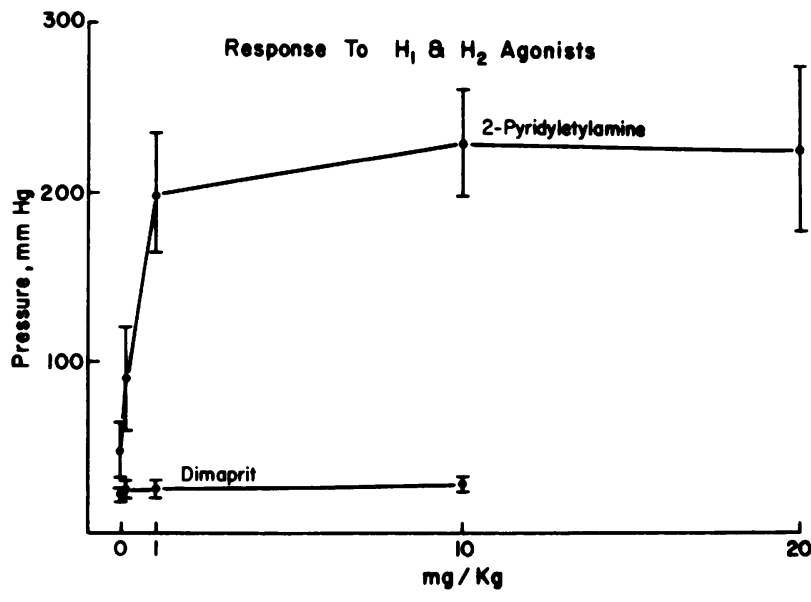

Figure 6 Dose-response curves for the specific $H_{1}$ agonist 2-pyridyletylamine $(n=3)$ and for the specific $\mathrm{H}_{2}$ agonist dimaprit $(n=2)$. All values are mean \pm SEM.

specific $\mathrm{H}_{1}$ agonist, produced a pyloric response similar to that observed with histamine whereas dymaprit, an $\mathrm{H}_{2}$ agonist, caused very low-grade contractions.

Tetrodotoxin $(20 \mu \mathrm{g} / \mathrm{kg})$ significantly diminished the response to histamine (Fig. 7) in a noncompetitive way, suggesting that a large part of the histamine response may be nerve mediated. To investigate the nature of the nerve-mediated portion of the histamine response, various cholinergic and adrenergic antagonists were used. Hexamethonium $(40 \mathrm{mg} / \mathrm{kg}$ ) and atropine $(30$ $\mu \mathrm{g} / \mathrm{kg}$ ) in combination did not affect the histamine response, suggesting that the nerve-mediated portion of the histamine response is not mediated through cholinergic neural fibers.

Propranolol, in the dose of $1 \mathrm{mg} / \mathrm{kg}$, had no effect on the histamine response, indicating that the nervemediated portion of the histamine response is not

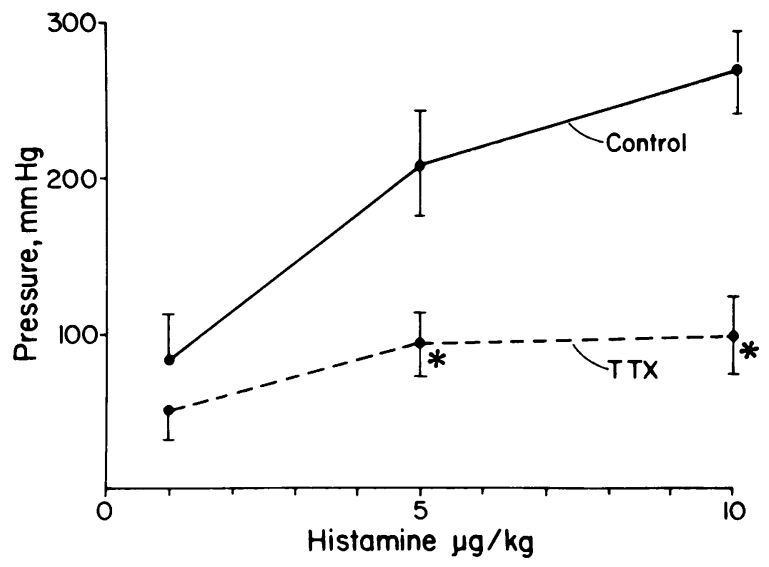

FIgURE 7 Effect of tetrodotoxin (TTX, $n=8$ ) on histamine dose-response curves. Stars denote statistically significant differences from control values $(n=8)$. 


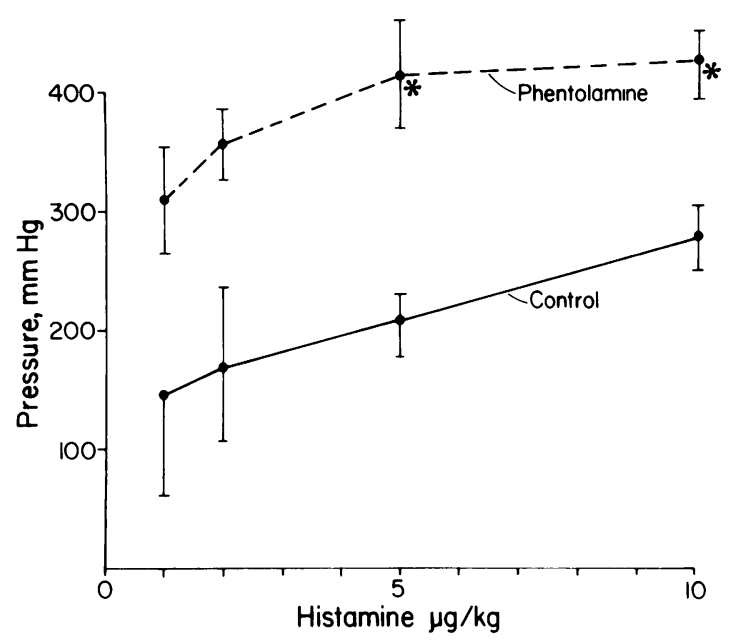

FIGURE 8 Effect of phentolamine $(n=5)$ on histamine doseresponse curves. Control $(n=5)$.

mediated through beta adrenergic nerves. The effect of alpha adrenergic inhibition and of catecholamine depletion on the histamine response was also determined. The dose of $1 \mathrm{mg} / \mathrm{kg}$ phentolamine, as shown in Fig. 8, significantly increased the histamine response. To test the effect of catecholamine depletion, three animals were given $3 \mathrm{mg} / \mathrm{kg}$ of reserpine per day for $3 \mathrm{~d}$ and were tested on the 4 th $\mathrm{d}$. Reserpine-treated animals appeared to be sick, developed diarrhea, and were hypotensive. The completeness of the catecholamine depletion was tested with tyramine; before reserpine administration tyramine caused LES contraction and after reserpine no contraction was observed (13).

Reserpine-treated cats exhibited higher histamine response than untreated animals (Fig. 9). The increase was significant at $1 \mathrm{mg} / \mathrm{kg}$ of histamine $(P<0.5)$.

Because these data pointed to an inhibitory effect of the histamine response by catecholamines, this point was checked in three animals. The animals were given histamine $(10 \mu \mathrm{g} / \mathrm{kg})$ and $2 \mathrm{~min}$ after the onset of the phasic contractions they received $50 \mu \mathrm{g} / \mathrm{kg}$ i.v. of phenylephrine. After $10 \mu \mathrm{g} / \mathrm{kg}$ of histamine, the phasic contractions normally last 5-10 min; after phenylephrine, however, they immediately cease.

\section{DISCUSSION}

The gastroduodenal junction of the cat exhibits a distinctive response to histamine in amounts similar to those required to produce maximal secretory stimulation.

The response consisted of strong repetitive phasic contractions, $300 \mathrm{mg} \mathrm{Hg}$ in average amplitude lasting 5-10 min after injection of $10 \mu \mathrm{g} / \mathrm{kg}$ i.v. of histamine and localized in a 2-3-mm zone located at the anatomic pylorus. This same zone exhibits elevated pressure in the resting state with respect to adjacent location and relaxes in response to efferent vagal stimulation. Further, the high amplitude response to histamine is confined to the pyloric sphincter area; in fact, great care must be exerted in placing the catheter precisely within the high pressure zone to obtain a reliable and elevated response. Misplacement of the catheter, even by 2 or 3 $\mathrm{mm}$, results in absence of response. Only rarely are antral contractions present, and duodenal contractions sometimes occur but are always much lower in magnitude than the pyloric contractions.

This response to histamine is unique and unlike previously reported pyloric responses to a variety of other agents, including pentagastrin, bethanechol, cholecystokinin, and phenylephrine (11), or secretin, dopamine, metoclopramide, prostaglandin $E_{2}$ or $F_{2} a$ (unpublished observations).

The amplitude of the histamine-induced contractions is surprising. Both in vivo and in vitro the pylorus is capable of relatively low tonic contraction. For instance, compared with the LES, the active component of resting pressure in the cat pylorus in vivo is only $10-20 \mathrm{~mm} \mathrm{Hg}(11)$ compared with $40-50 \mathrm{~mm} \mathrm{Hg}$ for the resting pressure in the LES. When the in vivo pylorus is stimulated by inotropic agents such as bethanechol, norepinephrine, or by electric stimulation of vagal afferent fibers, the pressure increases only by $10-15 \mathrm{~mm} \mathrm{Hg}$, yielding total pressures of the order of $30 \mathrm{~mm} \mathrm{Hg}$ whereas the stimulated LES is capable of producing pressures of $60-80 \mathrm{~mm} \mathrm{Hg}$. Similarly, the in vitro pylorus, when maximally stimulated by $\mathrm{KCl}$, yields tonic contractions of $7 \mathrm{~g}$ active force for rings $1.75 \mathrm{~mm}$ wide (14) whereas similar LES rings contract with $11 \mathrm{~g}$ of force (15). Thus, it appears that with respect to tonic contraction the pylorus is capable of only relatively low forces or pressures, certainly lower than the

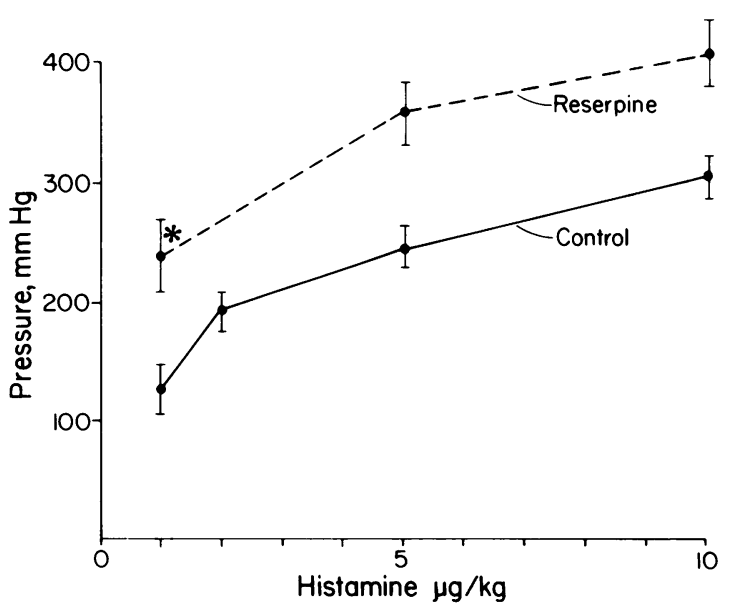

Figure 9 Effect of catecholamine depletion by reserpine $(n=3)$ on histamine dose-response curves. Control $(n=20)$. 
LES. The pylorus, however, has such a marked ability to develop large phasic contractions in response to histamine that one is bound to speculate whether two different mechanisms may be involved in generating phasic vs. tonic contractions. The fact that different mechanisms may be involved is further supported by the finding that whereas alpha adrenergic blockade with phentolamine reduces the resting pressure in the pylorus by $\sim 39 \%$, from 15 to $11 \mathrm{~mm} \mathrm{Hg}(10)$, the same dose of phentolamine augments the response to histamine $(10 \mu \mathrm{g} / \mathrm{kg})$ from 280 to $430 \mathrm{~mm} \mathrm{Hg}$ or a $54 \%$ increase. It should be further noted that contractions of this amplitude are unusual, at least in the cat, not only in the small intestine but also in the esophagus. The reason for such large contractions is not clear.

The phasic contractions are mediated through $\mathrm{H}_{1}$ receptors. This conclusion is based on the finding that diphenhydramine, as $\mathrm{H}_{1}$ blocker, induced competitive inhibition of the histamine-induced contractions and in large enough doses $(20 \mathrm{mg} / \mathrm{kg})$ completely abolished them, whereas 2-pyridyletyl-amine, a specific $\mathrm{H}_{1}$ agonist, produced phasic contractions similar to those elicited by histamine.

$\mathrm{H}_{2}$-receptor stimulation by dymaprit, on the other hand, produced only very low $(30 \mathrm{~mm} \mathrm{Hg}$ ) contractions. The genesis of these contractions is not clear since an $\mathrm{H}_{2}$ blocker, cimetidine, did not reduce the amplitude of the histamine-induced contraction.

In conclusion, on the basis of these data, there is clear evidence that the major excitatory receptors are $\mathrm{H}_{1}$ in type, but there is little evidence that $\mathrm{H}_{2}$ receptors play a significant role in the histamine-induced phasic contractions.

Tetrodotoxin (TTX) in doses sufficient to completely inhibit neural transmission partly antagonized the response to histamine, in a noncompetitive way, by reducing the response by $\sim 60 \%$ at the doses used. This finding suggests that the excitatory response to histamine is only partly myogenic and that some of the $\mathrm{H}_{1}$ receptors that mediate the response may be located on neural structures. That TTX may inhibit the effect of histamine on the pylorus through direct action on the muscle membrane cannot be completely excluded. This possibility, however, seems unlikely since TTX has no antihistaminic properties in the guinea pig ileum (16), which is directly affected by histamine.

Moreover, it has been shown that histamine may cause muscle contraction of the guinea pig and kitten isolated stomach by acting on ganglionic synapses of cholinergic neurons (5) since the histamine-induced contraction was reduced by hexamethonium and by hyoscine. In the guinea pig stomach, TTX also reduces the amplitude of the histamine response (16). Thus it appears that histamine is capable of acting on gastric neural structures. The neural structures mediating the histamine response in the cat pylorus, however, are noncholinergic since this response is not affected by atropine and hexamethonium in doses sufficient to completely abolish pyloric relaxation in response to electrical stimulation of the vagus (11).

To determine whether the histamine response is mediated through an adrenergic pathway, we used the beta blocker, propranolol, and the alpha blocker, phentolamine. Propranolol had no effect on the histamine response. Phentolamine, however, significantly increased the amplitude of the histamine response. To confirm a possible adrenergic inhibitory effect on the histamine-induced excitation, we used reserpine. Reserpine is known to deplete catecholamines from storage sites in the nerve terminals. After catecholamine depletion, the histamine response was greater, suggesting that adrenergic block does not decrease, but rather increases, the magnitude of the histamine response. This point was further confirmed by the fact that the alpha agonist, phenylephrine, blocks the response to a dose of $10 \mu \mathrm{g} / \mathrm{kg}$ of histamine.

These data suggest that the pyloric response to histamine is due to a combination of actions occurring at various receptor sites. Neural and myogenic $\mathrm{H}_{1}$ receptors mediate excitation whereas $\mathrm{H}_{2}$ receptors have little or no effect. The neural $\mathrm{H}_{1}$ receptors may be located on nonadrenergic, noncholinergic excitatory neurons. Nonadrenergic, noncholinergic excitatory nerves have been previously demonstrated in other portions of the gut. In the guinea pig ileum $(17,18)$ and gallbladder (19), nonadrenergic, noncholinergic excitatory nerves have been shown, but histamine has been excluded as the final mediator of this excitation. It is possible that histamine may act in the cat pylorus by causing the release of a second messenger, which in turn would cause contraction.

It is tempting to speculate about a physiologic role of histamine in pyloric control. Gastric mucosa is one of the body tissues with the highest histamine content, in man and many animal species, both vertebrate and invertebrate (1). Histamine is probably involved in an important way in the gastric secretory process since histamine antagonism blocks the effect of other oxyntic cell stimulants. Finally, of three endogenous substances known to stimulate acid secretion, histamine, gastrin, and acetylcholine, histamine is the only one that produces such a prominent pyloric response. The pylorus responds to bethanechol with a $7-\mathrm{mm} \mathrm{Hg}$ increase in tonus; no response to pentagastrin occurred in 17 of 25 animals, and in the 8 animals that responded, only low level contractions $(5-15 \mathrm{~mm} \mathrm{Hg}$ ) occurred (11). Moreover, a pyloric response occurs at histamine doses as low as $5 \mu \mathrm{g} / \mathrm{kg}$ per h, which is less than the dose required to produce maximum acid secretory response in the same animal species (12). It is possible that if histamine is released in the secretory process, it may also stimulate the pylorus, preventing gastric 
emptying until digestion is initiated. In the absence of specific data, however, any such role of histamine remains purely speculative.

\section{ACKNOWLEDGMENTS}

In the course of this investigation, we have sought valuable advice from several investigators. We are particularly grateful to J. Behar, E. E. Daniel, R. K. Goyal, R. Levi, S. Rattan, M. Rosen, and R. M. Weiss. Pyridylethylamine and dimaprit were graciously provided by Smith Kline \& French Laboratories, Philadelphia, $\mathrm{Pa}$.

This work was supported by National Institutes of Health grant RO1 AM 16021.

\section{REFERENCES}

1. Reite, O. B. 1978. Comparative physiology of histamine. Physiol. Rev. 52: 778-819.

2. Guth, P. H., and E. Smith. 1978. Histamine receptors in the gastric microcirculation. Gut. 19: 1059-1063.

3. Gerner, T., J. F. W. Hafner, and J. Norstein. 1979. The effects of Mepyramine and cimetidine on the motor response to histamine, cholecystokinin, and gastrin in the fundus and antrum of isolated guinea pig stomachs. Scand. J. Gastroenterol. 14: 65-72.

4. Ohga, A., and T. Taneike. $1978 . \mathrm{H}_{1}$ and $\mathrm{H}_{2}$ receptors in the smooth muscle of the ruminant stomach. Br.J. Pharmacol. 62: 333-337.

5. Paton, W. D. M., and J. R. Vane. 1963. An analysis of the responses of the isolated stomach to electrical stimulation and to drugs. J. Physiol. (Lond.). 165: 10-46.

6. DeCarle, D., M. J. Brody, and J. Christensen. 1976. Histamine receptors in esophageal smooth muscle of the opossum. Gastroenterology. 70: 1071-1075.

7. Rattan, S., and R. K. Goyal. 1978. Effect of histamine on the lower esophageal sphincter in vivo: evidence for action at three different sites. J. Pharmacol. Exp. Ther. 204: 334-342.
8. Kravitz, J. J., W. J. Snape, and S. Cohen. 1978. Effect of histamine and histamine antagonists on human lower esophageal sphincter function. Gastroenterology. 74: 435-440.

9. Grossman, M. I. 1978. Control of gastric secretion. In Gastrointestinal Disease. M. H. Sleisenger and J. S. Fordtran, editors. W. B. Saunders Company, Philadelphia, Pa. 2nd edition. 640-659.

10. Dent, J., and M. B. Chir. 1976. A new technique for continuous sphincter pressure measurement. Gastroenterology. 71: 263-267.

11. Behar, J., P. Biancani, and M. P. Zabinski. 1979. Characterization of feline gastroduodenal junction by neural and hormonal stimulation. Am. J. Physiol. 236: E45-E51.

12. Emas, S., and M. I. Grossman. 1968. Acid response to graded doses of histamine and gastrin in Heidenhain pouch cats. Gastroenterology. 55: 72-75.

13. Behar, J., S. Field, and C. Marin. 1979. Effect of glucagon, secretin, and vaso-active intestinal polypeptides on the feline lower esophageal sphincter. Gastroenterology. 77: 1001-1007.

14. Biancani, P., M. P. Zabinski, and J. Behar. 1980. Mechanical characteristics of the cat pylorus. Gastroenterology. 78: 301-309.

15. Biancani, P., M. P. Zabinski, and J. Behar. Lower esophageal sphincter mechanics: anatomic and physiologic relationships of the esophago-gastric junction of cat. In press.

16. Gershon, M. D. 1967. Effects of tetrodotoxin on innervated smooth muscle preparations. Br. J. Pharmacol. Chemother. 29: 259-279.

17. Ambache, N., and M. A. Freeman. 1968. Atropine resistant longitudinal muscle spasm due to excitation of noncholinergic neurones in Auerbach's plexus. J. Physiol. (Lond.). 199: 705-727.

18. Ambache, N., J. Verney, and M. Aboo Zar. 1970. Evidence for the release of two atropine resistant spasmogens from Auerbach's plexus.J. Physiol.(Lond.). 207: 761-782.

19. Ambache, N., and M. Aboo Zar. 1970. Non-cholinergic transmission by post-ganglionic motor neurones in the mammalian bladder. J. Physiol. (Lond.). 210: 761-783. 